\title{
Investigating the effect of self-cleaning treatment on the air permeability, stain removal and water repellency properties of functionalized double jacquard woven upholstery fabrics
}

\author{
DOI: $10.35530 / I T .070 .06 .1483$
}

\section{ABSTRACT - REZUMAT}

Investigating the effect of self-cleaning treatment on the air permeability, stain removal and water repellency properties of functionalized double jacquard woven upholstery fabrics

Self-cleaning is the important and required function for the upholstery fabrics. At this research, which was not studied in the references, nano $\mathrm{TiO}_{2}$ coating was appliqued on 18 double faced woven fabrics produced with jacquard weaving technique with three different weft density, two different raw materials of warp yarns that are polyester and rayon, three different face weave pattern under the same conditions by using sol-gel method. All fabrics were stained with the same amount of coffee. Self-cleaning efficiency of the applied fabrics were tested at spectrophotometer by using K/S (Colour/Strength) values after waiting 6, 12 and 24 hours under artificial sunlight and stain removal ratios were calculated. The effects of the fibre type, weft setting and weave pattern on the air permeability of upholstery fabrics were investigated by variance analysis by means of Minitab 17.0. $\mathrm{TiO}_{2}$ application caused air permeability reduction of $18-40 \%$ in polyester warp fabrics and $30-47 \%$ in rayon warp fabrics. It was seen that self-cleaning property can be got at double faced polyester/cotton and rayon/cotton fabrics by using nano $\mathrm{TiO}_{2}$. After 24 hours sunlight exposure, the average stain removal rates were found as $74.8 \%$ for polyester warp fabrics and $66.7 \%$ for rayon warp fabrics. Also, it has been observed that $\mathrm{TiO}_{2}$ application imparts hydrophobic properties to all rayon and polyester warp fabrics.

Keywords: double woven fabrics, nanoTiO ${ }_{2}$, self-cleaning, sol-gel method, fabric construction, air permeability, stain removal ratio, contact angle

Investigarea influenței tratamentului de autocurățare asupra proprietăților de permeabilitate la aer, îndepărtarea petelor și impermeabilitate la apă ale țesăturilor jacard duble pentru tapițerie funcționalizate

Autocurățarea este o funcție importantă și necesară țesăturilor pentru tapițerie. În cadrul acestei cercetări, un nanostrat de $\mathrm{TiO}_{2}$ a fost aplicat, în aceleași condiții, pe 18 țesături cu două fețe realizate prin tehnica de țesere cu mecanism jacard, cu trei desimi diferite ale bătăturii, două materii prime diferite pentru firele de urzeală, și anume poliester și viscoză, trei legături diferite pe fața țesăturii, folosind metoda sol-gel. Toate țesăturile au fost pătate cu aceeași cantitate de cafea. Eficiența de autocurățare a țesăturilor tratate a fost testată la spectrofotometru, prin utilizarea valorilor K/S (Culoare/Rezistență), după expunere timp de 6, 12 și 24 de ore, sub lumină artificială și calculul raportului de îndepărtare a petelor. Au fost analizate influențele tipului de fibră, ale desimii în bătătură și ale legăturii asupra permeabilității la aer a țesăturilor pentru tapițerie prin analiza varianței cu Minitab 17.0. Aplicarea de TiO ${ }_{2}$ a determinat reducerea permeabilității la aer cu 18-40\% pentru țesăturile cu urzeală din poliester și cu 30-47\% pentru țesăturile cu urzeală din viscoză. S-a observat că proprietatea de autocurățare poate fi obținută la țesăturile cu două fețe din poliester/bumbac și din viscoză/bumbac cu legături identice, folosind nano $\mathrm{TiO}_{2}$. După 24 de ore de expunere la soare, s-a constatat că raporturile medii de îndepărtare a petelor au fost de $74,8 \%$ pentru țesăturile cu urzeală din poliester și

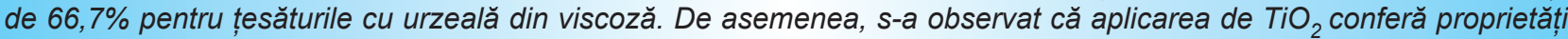
hidrofobe tuturor țesăturilor cu urzeală din viscoză și din poliester.

Cuvinte-cheie: țesături duble, nano $\mathrm{TiO}^{2}$, autocurățare, metoda sol-gel, structura țesăturii, permeabilitatea la aer, raport de îndepărtare a petelor, unghiul de contact

\section{INTRODUCTION}

Researches and applications of eco-friendly functions as self-cleaning property has been rising recently by increasing of awareness to the environment. The usage of these materials is in electronic, automotive, glass, dye, construction, textile industry as well as in various industrial areas like filters, packaging, metal anticorrosion, etc.

The semiconductor photo catalyst technology is the most efficient method which is favoured at decreasing of the nature pollution. At this technology, which can be activated by the help of sunlight, $\mathrm{TiO}_{2}, \mathrm{ZnO}$, $\mathrm{Fe}_{2} \mathrm{O}_{3}, \mathrm{CdS}, \mathrm{WO}_{3}, \mathrm{SnO}_{2}$ and $\mathrm{ZnS}$ can be used as photo catalysts. The semiconductors can mineralize the adsorbed biodegradable organic compounds and convert to $\mathrm{CO}_{2}$ and $\mathrm{H}_{2} \mathrm{O}$ by using sunlight [1].

The most common photo catalyst in textile is $\mathrm{TiO}_{2}$. It gets ahead because of many advantages like (1) its low toxicity, (2) applicability at ambient temperature and pressure, (3) mineralization ability of organic 
compounds without bringing on a secondary pollution, (4) low operation cost, (5) ability to destroy various pollutant, (6) activation capability under indoor or outdoor light [1].

Self-cleaning surfaces can be appliqued by several methods like electrospinning, etching, moulding, etc. [2]. Besides, by coating method (dip-coating, spincoating, spray-coating), it can be appliqued to all surfaces in a cheaper and faster way. Another coating method is sol-gel which has wide usage at transparent coating. By using this method, chemical and physical properties of chemical compounds can be adapted according to intended hydrophobicity, stability, flexibility and porosity [3].

Qui et al. [4], made experiments about an atase $\mathrm{TiO}_{2}$ application on cotton fabric by sol-gel process. At their study, transparent thin film was obtained on fibre surface with dip-pad-dry-cure process. It is seen that rigidity was increased by $13 \%$ and the air permeability was reduced by $0.76 \%$ after $\mathrm{TiO}_{2}$ treatment. Also it was tested degradation of coffee, red wine and curry stains on treated fabrics.

Factors like raw material, yarn properties, fabric type, knitting structure and fabric thickness effect the air permeability of fabrics as well as determine their physical, mechanic, sensory properties [5].

Gupta et al. [6] applied Nano $\mathrm{TiO}_{2}$ on the cotton fabric (plain weave; $113 \mathrm{~g} / \mathrm{m}^{-2}$; and EPI×PPI, $110 \times 82$ ) by sol-gel method without using any cross-linkers or adhesives. It was seen that cotton fabrics after $1 \mathrm{wt} \%$ $\mathrm{TiO}_{2}$ application had showed considerable self-cleaning activity for coffee stain when exposed to light for 12-48 hours. They had seen fast cleaning in the first 12 hours and stabilization after 48 hours. The decrease in the K/S value on the cotton fabric treated with the water-treated Nano-solution of $\mathrm{TiO}_{2}$ was $64.1 \%$ after 12 hours, $73.0 \%$ after 24 hours, and $76.5 \%$ after 48 hours.

Shahba et al. [7] investigated the effects of weaving construction of PES fabrics and its blend with cotton yarn on the self-cleaning efficacy after treatment with $\mathrm{TiO}_{2}$ nanoparticles. Three different blending ratio fabrics were formed by using two types of yarn material. Three kind of weaving construction and picks number were used for each blending ratio. It was seen that, the highest degree of self-cleaning properties was observed with satin-4 weaving construction, whereas the least degree of self-cleaning was seen at plain $1 / 1$ weaving construction. In addition, intermediate values of self-cleaning was observed at twill 4/4 weaving construction. It has been observed that in the same weaving construction, when the number of peaks was raised from 24 to 36 pick $/ \mathrm{cm}$, the selfcleaning properties of the fabrics showed a decrease in the degree of self-cleaning. It was also noted that $100 \%$ PES fabrics treated with $\mathrm{TiO}_{2}$ nanoparticles have the highest self-cleaning properties compared to the PES/cotton blend fabrics at the same picks number and weaving construction.

Ignat et al. [8] used synthesized $\mathrm{TiO}_{2}$ nanoparticles doped with different elements which have shown an improvement of the photocatalytic decomposition of organic pollutant models such as Orange II, Methylene Blue or ball pen ink in solution or on leather surface exposed to UV and/or Vis radiations. The use of doped $\mathrm{TiO}_{2}$ nanoparticles on leather surface showed soil repellency through contact angle increased values and self-cleaning properties under UV-Vis radiation exposure.

Zhang, Cai and Wang [9] introduced a photocatalytic material (the nano-sized titanium dioxide) into poly (lactic acid) (PLA) to produce films with self-cleaning function. Prototypes containing 0, 5, 10, 15 and 20 $w t \%$ nano filler were prepared and then etched with proteinase $\mathrm{K}$ to expose the nano particles on the surface. The self-cleaning function was assessed by the discoloration of methylene blue (MB) in aqueous condition via a UV-vis spectrophotometer. The samples containing $15 \mathrm{wt} \%$ nano filler could totally degrade the methylene blue after $24 \mathrm{~h}$ UV irradiation.

Although there are many studies on the application of $\mathrm{TiO}_{2}$ on fabric, a similar study comparing fabric construction on the basis of double weaving has not been encountered. At this study, $\mathrm{TiO}_{2}$ had been appliqued on polyester/cotton, rayon/cotton fabrics which had various weft density and face weave pattern by solgel method. The changes on air permeability and self-cleaning properties of fabrics according to their raw material, weft density and face weave pattern were investigated.

\section{EXPERIMENTAL}

\section{Materials}

Acetic Acid (Glacial 100\%-EMSURE, Amerikan Chemical Society, International Organization for Standardization, Reagents the European Pharmacopoeia-anhydrous for analysis) and Nitric Acid 65\% (extra pure) were purchased from Merck. Titanium (IV) Isopropoxide (\%97) was supplied from Sigma Aldrich.

In this research 18 kinds of self-stitched double woven fabric samples, whose face weave pattern have been 5 s sateen, 10 s sateen, 20 s sateen and back weave has been $5 \mathrm{~s}$ sateen, were been produced in Mega Textile Industry and Trade Inc. by Dornier machine with rapier picking mechanism. 150 denier of filament polyester yarn with twist of $160 \mathrm{tpm}$ in S direction and of filament rayon yarn with twist of $500 \mathrm{tpm}$ in S direction were used as warp yarns. In addition to this, Ne 30/2 cotton yarn with twist of $710 \mathrm{tpm}$ in $\mathrm{S}$ direction was planned as weft yarns. Warp settings of fabric samples were $66 \mathrm{~cm}^{-1}$, weft settings of fabric samples were $32 \mathrm{~cm}^{-1}, 35 \mathrm{~cm}^{-1}$ and $38 \mathrm{~cm}^{-1}$ [10]. Fabric samples were coded according to weft density, raw material of warp yarns and of weft yarns, face weave pattern as in table 1. The numbers in fabric codes represent weft densities, raw materials of warp yarns and of weft yarns, face weave patterns respectively. These are square unit weaves, so the number of each warp and weft yarn interlacing is equal to each other, namely the average yarn interlacing is equal to number of yarn interlacing. 
The fabric property, the weave interlacing coefficient, defined by Galcerán [11] has been calculated by:

$$
K L=\frac{i}{w_{1} \times w_{2}}
$$

where $i$ is the number of interlacing points in weave repeat, $w_{1}$ - the number of ends in weave repeat, $w_{2}$ - the number of picks in weave repeat.

And also the average float length of warp yarn is equal to the average float length of weft yarn. The average float length $F$ has been calculated according to Ashenhurst [12] by equation (2):

$$
F_{1 / 2}=\frac{R_{2 / 1}}{t_{1 / 2}}
$$

where: $R_{2 / 1}$ is the weft (2) or warp (1) repeat; $t_{2 / 1}$ - the number of warp of weft intersections in the weave repeat. Type of weave pattern can be seen in figure 1.

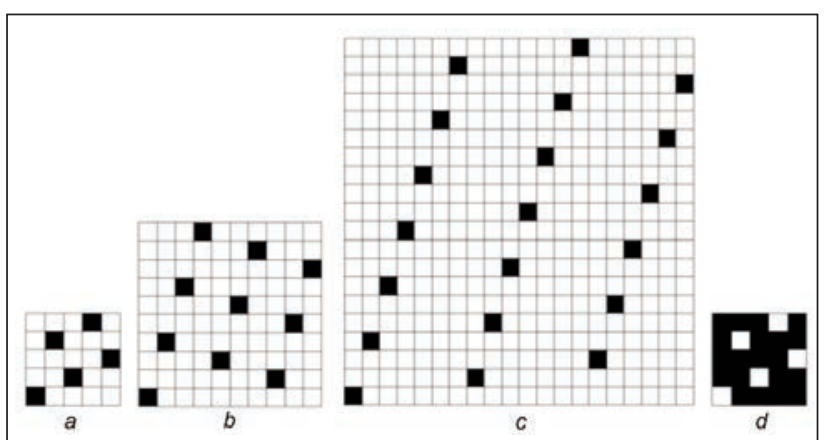

Fig. 1. Weave patterns: $a-5$ s sateen; $b-10$ s sateen; $c-20$ s sateen; $d-5$ s satin
The technical properties of sample fabrics are introduced in table 1.

\section{Method}

\section{Preparing of Sol-Gel}

Chemical applied on fabrics was prepared by sol-gel method at laboratories of YÜNSA Worsted and Woollen Production and Trading Co. Softened water inside the beaker was put on heater. While it was being mixed violently with mechanic stirrer at 1200 rpm, Acetic Acid, Nitric Acid and Titanium (IV) Isopropoxide (TTIP) were added into the solution. Heater was set to $80^{\circ} \mathrm{C}$. It is being gone on stirring at this temperature until homogeny, transparent view occurs in the solution. A few hours later, $\mathrm{TiO}_{2}$ nanoparticles (NP) were obtained [13].

\section{Application Method}

The application of the prepared solution on fabrics is performed at mini stenter which was placed in finishing department of YÜNSA Worsted \& Woollen Production and Trading Co. Washed and dried fabrics were passed into the solution diluted in the ratio of $1 / 2$. After squeezing at 7.5 bar pressurized cylinder, they were passed through drying and fix cabins at $180{ }^{\circ} \mathrm{C}$ with $1 \mathrm{~m} / \mathrm{min}$ velocity. The velocity of fans was set at 1800 cycle/min.

\section{Air Permeability Test Method}

The fabric samples were conditioned at standard atmosphere conditions $\left(20 \pm 2^{\circ} \mathrm{C}, \% 65 \pm 2\right.$ relative humanity) for 24 hours. Air permeability of fabrics

\begin{tabular}{|c|c|c|c|c|c|c|}
\hline Number & $\begin{array}{c}\text { Weft } \\
\text { density }\end{array}$ & $\begin{array}{l}\text { Raw material } \\
\text { of warp yarns }\end{array}$ & $\begin{array}{l}\text { Raw material } \\
\text { of weft yarns }\end{array}$ & $\begin{array}{c}\text { Face weave } \\
\text { pattern }\end{array}$ & $\begin{array}{l}\text { The weave } \\
\text { interlacing coefficient }\end{array}$ & $\begin{array}{l}\text { The average } \\
\text { float length }\end{array}$ \\
\hline 1 & 32 & Polyester & Cotton & 5s sateen & 0.4 & 2.5 \\
\hline 2 & 32 & Polyester & Cotton & 10 s sateen & 0.2 & 5 \\
\hline 3 & 32 & Polyester & Cotton & 20s sateen & 0.1 & 10 \\
\hline 4 & 35 & Polyester & Cotton & 5s sateen & 0.4 & 2.5 \\
\hline 5 & 35 & Polyester & Cotton & 10 s sateen & 0.2 & 5 \\
\hline 6 & 35 & Polyester & Cotton & 20s sateen & 0.1 & 10 \\
\hline 7 & 38 & Polyester & Cotton & 5s sateen & 0.4 & 2.5 \\
\hline 8 & 38 & Polyester & Cotton & 10 s sateen & 0.2 & 5 \\
\hline 9 & 38 & Polyester & Cotton & 20 s sateen & 0.1 & 10 \\
\hline 10 & 32 & Rayon & Cotton & 5s sateen & 0.4 & 2.5 \\
\hline 11 & 32 & Rayon & Cotton & 10 s sateen & 0.2 & 5 \\
\hline 12 & 32 & Rayon & Cotton & 20 s sateen & 0.1 & 10 \\
\hline 13 & 35 & Rayon & Cotton & 5s sateen & 0.4 & 2.5 \\
\hline 14 & 35 & Rayon & Cotton & 10s sateen & 0.2 & 5 \\
\hline 15 & 35 & Rayon & Cotton & 20s sateen & 0.1 & 10 \\
\hline 16 & 38 & Rayon & Cotton & 5s sateen & 0.4 & 2.5 \\
\hline 17 & 38 & Rayon & Cotton & 10 s sateen & 0.2 & 5 \\
\hline 18 & 38 & Rayon & Cotton & 20s sateen & 0.1 & 10 \\
\hline
\end{tabular}

TECHNICAL PROPERTIES OF SAMPLE FABRICS 
was tested in reference to TS 391 EN ISO 9237 standard.

Textile material is put under the head of test device the way that it is not wrinkle. $5 \mathrm{~cm}^{2}$ experiment space is placed on the surface of circular fabric holder. The air vacuum system is run and the test is gone on until the pressure difference between two faces of the fabric reaches to $200 \mathrm{~Pa}$ by gradually increasing the air flow which is passed from inside of specific area of the sample. The air flow amount which is passed from inside of the fabric is recorded as $\mathrm{I} /\left(\mathrm{m}^{2} \cdot \mathrm{s}\right) .10$ tests were done by taking homogeny samples from side-middle-side areas of the fabrics.

\section{Self-CleaningFunctionality Test Method}

Treated fabrics were soiled with $0.4 \mathrm{ml}$ coffee. To evaluate the self-cleaning functionality of stained fabrics, they were left under the artificial sunlight irradiation (xenon arc lamp) for 6, 12, and 24 hours. K/S values of the stained fabrics were measured before and after exposing the sunlight by spectrophotometer.

The effectiveness of stain degradation was tested using Q-Sun light fastness measurement device. After some periods of time sunlight exposure, the changes on K/S values of stained fabrics were monitored by Data colour 600 dual-beam spectrophotometer.

\section{Statistical evaluation}

Obtained air permeability results were analysed statistically by the help of Minitab 17 program. It was verified that general linear model of before and after finishing had worked with $95 \%$ precision level. During variance analyses, it was realized that "*” marked $P$ values were statistically important for $95 \%$ precision level.

\section{RESULTS AND DISCUSSIONS}

The air permeability of untreated and treated fabrics was tested. The decrease of the air permeability values of all fabrics after self-cleaning application can be seen in figure 2 . While decreasing ratio at polyester warp fabrics were seen between 18 and $40 \%$, as for $30-47 \%$ at rayon warp fabrics.

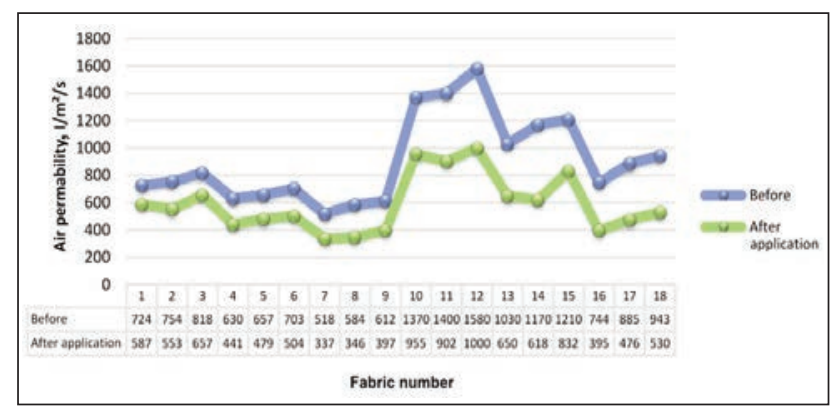

Fig. 2. The average air permeability of the fabrics as before and after application

Variance analyses of before and after application on fabrics are given in table 2 .

Interaction comparison graphics of the fabrics before self-cleaning application are presented in figure 3, a. As seen in figure $3, a$, the air permeability values

\begin{tabular}{|l|c|c|c|c|}
\hline \multicolumn{5}{|c|}{ VARIANCE ANALYSES } \\
\hline \multicolumn{1}{|c|}{ Source } & \multicolumn{1}{|c|}{ Before finishing } & \multicolumn{2}{c|}{ After finishing } \\
\cline { 2 - 5 } & $\mathbf{F}$ & $\mathbf{P}$ & $\mathbf{F}$ & $\mathbf{P}$ \\
\hline Weft density & 383.450 & $0.000^{*}$ & 103.9 & $0.000^{*}$ \\
\hline $\begin{array}{l}\text { Raw material } \\
\text { of warp yarns }\end{array}$ & 1720.880 & $0.000^{*}$ & 124.07 & $0.000^{*}$ \\
\hline $\begin{array}{l}\text { Face weave } \\
\text { pattern }\end{array}$ & 49.700 & $0.001^{*}$ & 8.89 & $0.034^{*}$ \\
\hline $\begin{array}{l}\text { Weft density } \\
\text { Raw Material } \\
\text { of warp yarns }\end{array}$ & 98.500 & $0.000^{*}$ & 12.02 & $0.020^{*}$ \\
\hline $\begin{array}{l}\text { Weft density* } \\
\text { Face weave } \\
\text { pattern }\end{array}$ & 2.040 & 0.254 & 0.74 & 0.609 \\
\hline $\begin{array}{l}\text { Raw Material of } \\
\text { warp yarns } \\
\text { weave pattern }\end{array}$ & 7.450 & $0.045^{*}$ & 0.93 & 0.466 \\
\hline
\end{tabular}

decreased by increasing weft density. When we compare polyester and rayon warp fabrics, it is seen that rayon warp fabrics which is produced from regenerated cellulose fibres as filament, softy and flexible structure, and has similar touch and brightness properties with silk had more air permeability than polyester which has synthetic structure. This is due to the fact that regenerated cellulous yarn, namely rayon, is more fibrous and porous than polyester yarn. Therefore, the porosity of the fabrics woven by rayon warps increase because of the air pressure during the air permeability test and these fabrics become more permeable.

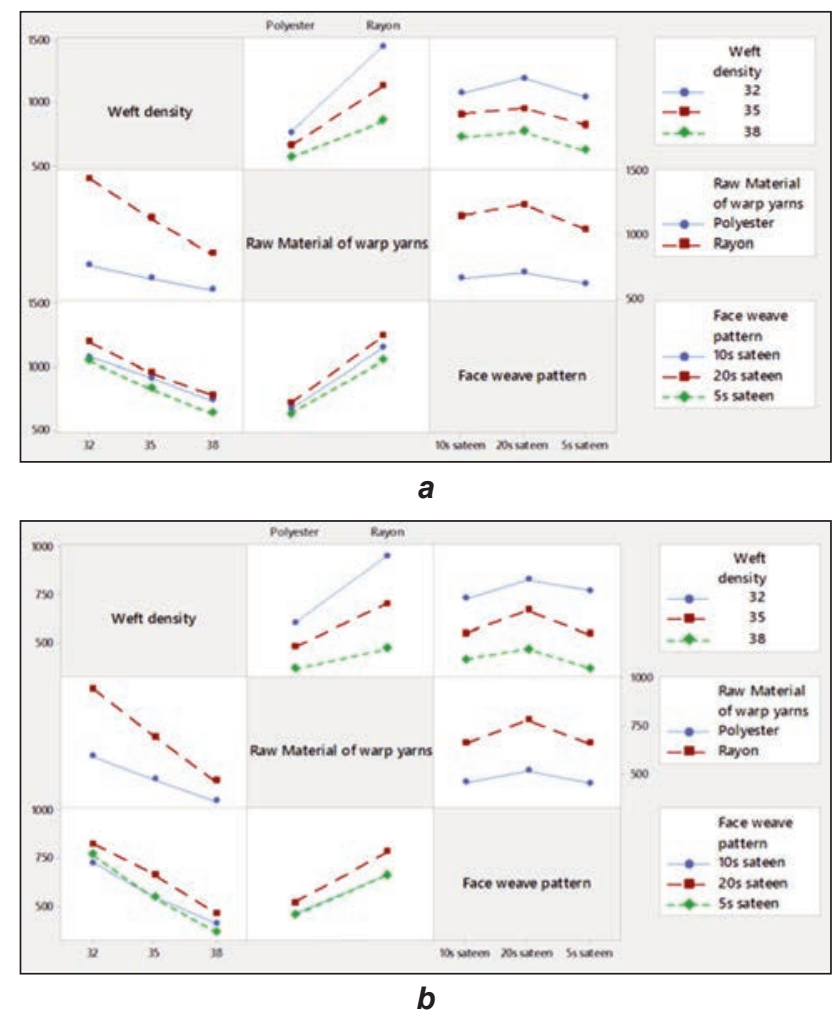

Fig. 3. Interaction plot of air permeability of fabrics: $a$ - before and $b$ - after finishing 
At Hristian's work [14], after testing the air permeability of the fabrics woven with Wool, Wool/Polyester, Wool/Polyester/Dorlastan and Polyester/Rayon yarns, they had seen that rayon content fabrics had more air permeability than others.

When the face weave sateen numbers are compared, a rise is obtained at air permeability by increasing the average float length and decreasing weave interlacing coefficient. As it was expected, it is monitored that the fabrics have more air permeability values by having more open area on surface.

It can be followed from figure $3, b$ that the air permeability of all fabrics goes down after self-cleaning application but the interactions between weft density, raw material and face weave sateen numbers look similar at before and after application.

After self-cleaning application, polyester warp specimens showed a reduction of $29.06 \%$ in air permeability averages, while Rayon warp specimens showed a reduction of $49.43 \%$. The reason is that there were more chemical attraction and adhesion at the cellulose-based regenerated fibre, Rayon, than polyester. Due to the high ratio of polyester crystalline region and polar structure, the moisture retention is low. Water molecules can only attach to the fibre surface in the form of a molecular film layer. It absorbs up to $0.4 \%$ moisture at room temperature and under standard conditions. Because of its structural condition, the rate of decrease in air permeability was observed less due to the less adherent coating.

Existence of self-cleaning functionality on the stained fabrics is tested before and after 6, 12 and 24 hour's artificial sunlight exposure. As seen in figure 4, K/S values of all stained fabrics at $400 \mathrm{~nm}$ are falling down as time passes by.

When we look at first states of fabrics called as unexposed, despite the same amount of coffee being spilled, after 4 hours minimum take-over is seen at fabric 4 which was woven with weft density of 35 , polyester warp yarns and 5 s sateen face weave pattern and fabric 18 which was woven with weft density of 38 , rayon warp yarns and 20 s sateen face weave pattern.

Among the fabrics exposed to the sunlight for 6 and 12 hours, the ones having the least stain are the fabrics 12 and 3 respectively. After 24 hours sunlight exposure, minimum stain mark is seen at fabric 3 which was woven with weft density of 35 , polyester warp yarns and 20 s sateen face weave pattern. The

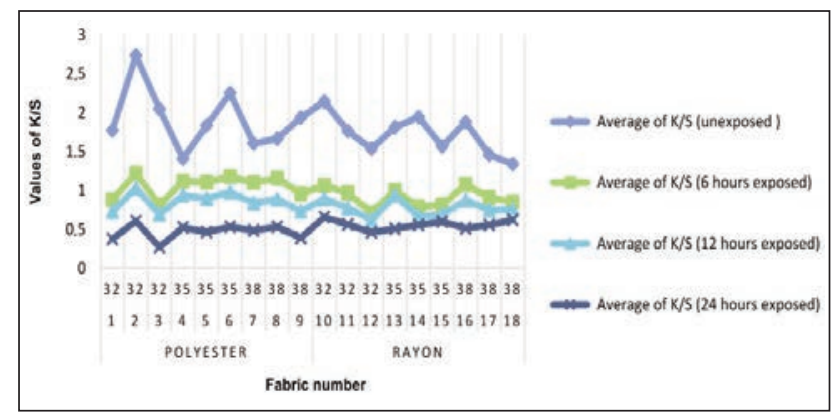

Fig. 4. K/S values of stained fabrics at $400 \mathrm{~nm}$ reason for not seeing any further decrease in the K/S values of the fabric numbered 12 after 24 hours is due to the natural brightness of rayon.

To check the self-cleaning ability according to fabric variety, stain removal percentage was calculated by using equation (3):
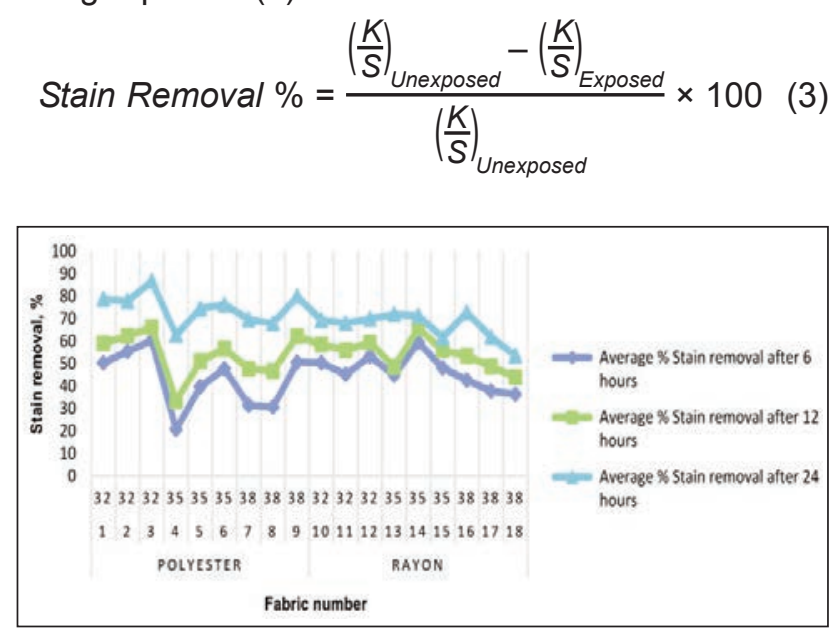

Fig. 5. Percentage change of stain removal due to fabric variety

As can be followed from figure 5 , stain removal ratios at polyester warp fabrics from 1 to 9 rise with increasing sateen number. We see the highest stain removal ratios at fabrics which were woven with weft density of 32 and also that polyester warp fabrics which were woven weft densities of 35 and 38 give similar results. When we look at rayon warp fabrics, it is seen the changes at sateen number did not affect the stain removal ratio forfabrics woven with weft density of 32. On the other hand, fabrics woven with weft densities of 35 and 38 , the stain removal falls down by rising sateen numbers. A slight decline is seen by increasing weft density at rayon warp fabrics but not like as being at polyester warp fabrics.

When we compare the stain removal ratios between polyester and cotton warp fabrics, the results show us the polyester warp fabrics are able to eliminate the stains more than the rayon warp fabrics at 32 weft density. On the other hand, the stain removal ratios of the rayon fabrics get close to the polyester fabrics results at 35 weft density. The results show that different removal ratios can be got for polyester and Rayon fabrics woven with weft density of 38 .

All fabrics were soiled with $0.4 \mathrm{ml}$ coffee. The initial and waited state $(6,12$ and 24 hours under artificial sunlight) of the fabric samples were presented in figure 6 and figure 7 respectively. The removal ratios were also promoted with the colour change visuals of stained fabrics as time progresses.

Besides of self-cleaning property, contact angles were tested to obtain water repellency effect of $\mathrm{TiO}_{2}$ between polyester and rayon warp fabrics. The results are given in figure 8 . Although rayon yarns have attraction to the water, rayon warp fabrics give similar contact angles with polyester warp fabrics after $\mathrm{TiO}_{2}$ application. Since all raw fabrics are 


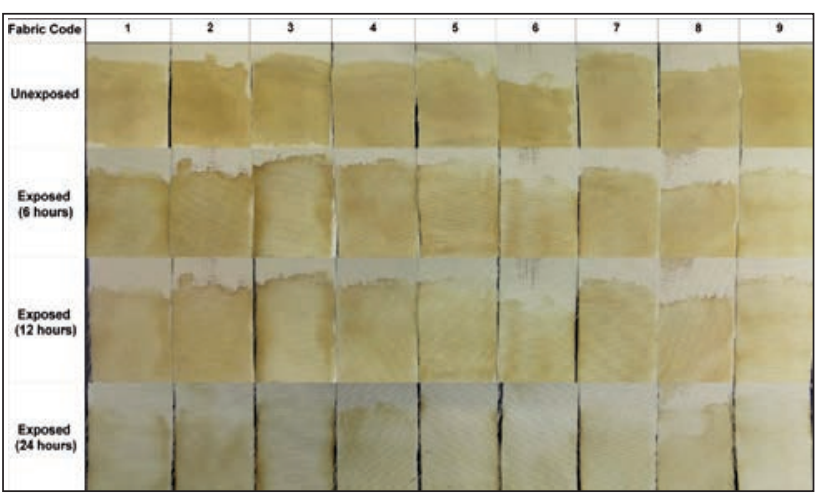

Fig. 6. Colour change of stained fabrics (1-9)

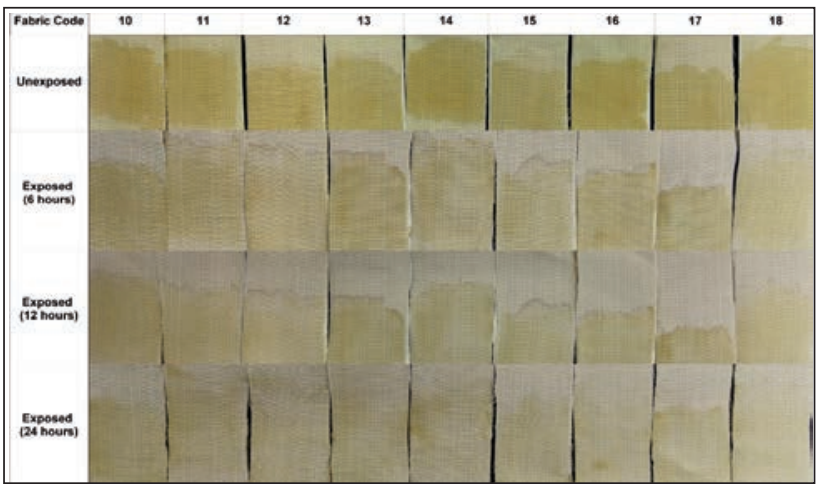

Fig. 7. Colour change of stained fabrics (10-18)

hydrophilic, all contact images are flat. All treated fabrics show hydrophobic property; even some of them are very close to being super hydrophobicity.

When contact angles are compared according to the raw materials warp yarn, the arithmetic average of the rayon warp fabrics was found to be lower 1 degree than that of polyester warp fabrics, but there was not found any statistical significance.

\section{CONCLUSION}

Air permeability and easy clean ability are the most desirable features in the upholstery fabrics. In this work, the double-faced upholstery fabrics are provided with self-cleaning properties without significantly reducing air permeability. After $\mathrm{TiO}_{2}$ application by sol-gel method, air permeability values of polyester and rayon warp fabrics decreased by $29.06 \%$ and $49.43 \%$, respectively. To test the self-cleaning feature, the fabrics stained with coffee were kept under artificial sunlight. The stain removal values $\%$ were calculated from the $\mathrm{K} / \mathrm{S}$ values measured in the spectrophotometer. Stain removal rates of stained polyester and rayon warp fabrics exposed to sunlight

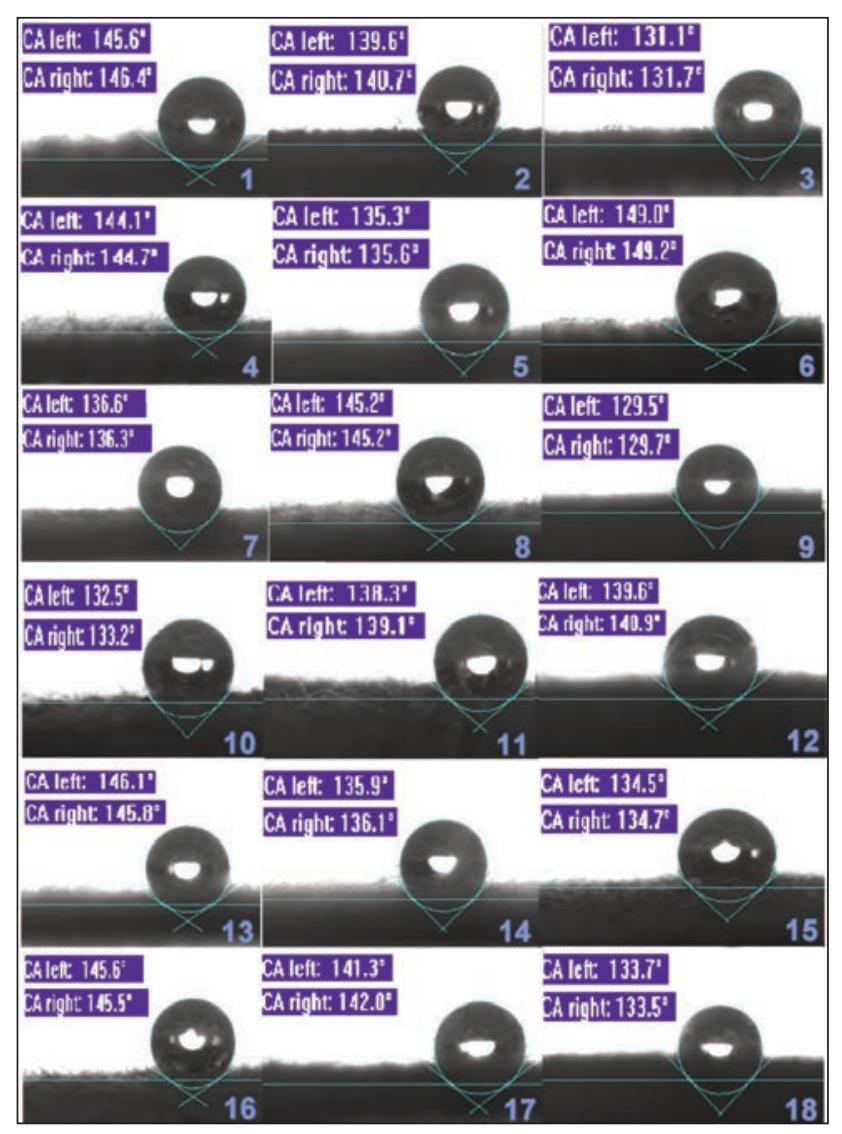

Fig. 8. Contact angle test results of $\mathrm{TiO}_{2}$ treated fabrics

were $42.9 \%$ and $46.4 \%$ after 6 hours, $53.9 \%$ and $54.4 \%$ after 12 hours, $74.9 \%$ and $66.7 \%$ after 24 hours, respectively. The K/S values of the rayon warp fabric do not fall more after a certain period of time, the reason is that the rayon has natural brightness. From the contact angle measurements, it was observed that $\mathrm{TiO}_{2}$ application caused hydrophobic effect on all fabrics which were hydrophilic before the application; even some fabrics have become super hydrophobic. Polyester warp fabric with 20 s sateen face weave pattern with 35 weft density and rayon warp fabric with $5 s$ sateen face weave pattern with 38 weft density were found the most suitable ones to be used as home textile upholstery fabric which is desired to be easily cleaned. As a continuation of the work, different warp and weft yarn raw materials, different face weave patterns can be tried or this work can also be done in single layer fabrics.

\section{ACKNOWLEDGEMENTS}

The author would like to thanks to workers of Yünsa Worsted \& Woollen Production and Training Co. for helps during experimental phase of this study.

\section{REFERENCES}

[1] Wang, J., Zhao, J., Sun, L., Wang, X., A Review on the Application of Photocatalytic Materials on Textiles, In: Textile Research Journal, 2015, 85, 10, 1104-1118

[2] Chen, J., Zhong, X., Lin, J., Wyman, I., Zhang, G., Yang, H., Wang, J., Wu, J., Wu, X., The Facile Preparation of Self-Cleaning Fabrics, In: Composites Science and Technology, 2016, 122, 1-9 
[3] Power, A.C., Barrett, A., Abubakar, J., Suarez, L.J., Ryan, L., Wencel, D., Sullivan, T., Regan, F., Versatile SelfCleaning Coating Production through Sol-Gel Chemistry, In: Advanced Engineering Materials, 2016, 18, 1, 76-82

[4] Qi, K., Wang, X., Xin, J.H., Photocatalytic self-cleaning textiles based on nanocrystalline titanium dioxide, In: Textile Research Journal, 2011, 81,1, 101-110

[5] Turan B veOkur A., Air Permeability in Fabrics, In: TMMOB Journal of Textile and Engineer, 2015, 72, 16-25

[6] Gupta, K.K., Jassal, M., Agrawal, A.K., Sol-gel derived titanium dioxide finishing of cotton fabric for self-cleaning, In: Indian Journal of Fibre \& Textile Research, 2008,33, 443-450

[7] Shahba, A.F., Bisi, M.E., Effect of weaving construction and blending ratio on self-cleaning properties of polyester and polyester/cotton blend fabrics treated with TiO2 nanoparticles, In: International Journal of Advance Research in Science and Engineering, 2015, 4, 6, 147-157

[8] Ignat, M., Petica, A., Gaidau, C., Dumitrescu, I., Surdu, L., Dinca, L., Ma, J.Z., Gao, J.J., Photocatlytic nanomaterials based on doped $\mathrm{TiO}_{2}$ for leather garments and upholstery with self-cleaning properties, In: Industria Textila, 2016, 67, 5, 308-313

[9] Zhang, C., Cai, X., Wang, F., Preparation and evaluation of the self-cleaning poly (lactic acid) (PLA) film blended with Titanium dioxide $\left(\mathrm{TiO}_{2}\right)$ nanoparticles, In: Industria Textila, 2016, 67, 2, 121-126

[10] Yavuzkasap D., A research on the mechanical properties of upholstery fabrics, MSc Thesis Dokuz Eylül University. The Graduate School of Natural and Applied Sciences, İzmir, Turkey, 2011

[11] Galceran, V., Weaving Technology, Technical University of Catalonia, Terrassa, (in Spanish), 1962

[12] Ashenhurt, T.R., A treatise on textile calculations and the structure of fabrics, Broadbent, Huddersfield, Yorkshire, 1884

[13] Palamutcu, S., Akman, O., Gulmez, S., Aydın, I., Selcuk, H. Functionalization of Wool Blend Fabrics Using TiO UTIB Turkish Textile and Clothing Sector VI. International R\&D Brokerage Event. Bursa, 3-4 April 2014

[14] Hritian, L., Researches Concerning The Air Permeability of Woven Fabrics Made from Combed Wool Yarns, In: Buletinul Institutului Politehnic din Iaşi, publicat de Universititatea Tehnica 'Georghe Asachi' din Iaşi, 2011, 57, 61, 2, 29-37

\section{Authors:}

\section{DUYGU YAVUZKASAP AYAKTA ${ }^{1}$, NAZLI ÇAĞLAR CINPERI ${ }^{1}$, HAKAN ÖZDEMIR ${ }^{2}$}

${ }^{1}$ Yünsa Worsted \&Woolen Production and Training Co, R\&D Center, 59500 Tekirdağ/Turkey

e-mail: dayakta@yunsa.com, textilengineer.duygu@gmail.com,ncinperi@yunsa.com, webpage: http://yunsa.com/en/

${ }^{2}$ Dokuz Eylül University, Department of Textile Engineering, $35390 \mathrm{Izmir} / T u r k e y$

e-mail: h.ozdemir@deu.edu.tr

Corresponding author:

DUYGU YAVUZKASAP AYAKTA

e-mail: dayakta@yunsa.com, textilengineer.duygu@gmail.com 